\title{
Information Systems Outsourcing: Reasons, Reservations and Success Factors
}

Claver, Enrique; González, Reyes; Gascó, José and Llopis, Juan.

Alicante University. Facultad de Ciencias Económicas y Empresariales. Departamento de Organización de Empresas. Carretera San Vicente-Alicante. 03080. Alicante. Spain. Fax and Phone Number: 34-96-5903606. E-mail: mr.gonzalez@ua.es

Bibliographic notes: Enrique Claver is a Full Professor in Business Management at the University of Alicante. Head of the Business Management Department at the said University. His current research interests include Strategic Management, Human Resources Management and Information Systems Management.

Reyes González is a Senior Lecturer in Business Management at the above-mentioned university. Her Ph.D. dissertation was an empirical research work on the Information Systems Departments in the Alicante area (east of Spain). Her current research interests are Information Systems Management, E-Business and Outsourcing Processes. José Gascó is a Senior Lecturer in Business Management at the University of Alicante. His Ph.D. dissertation was an empirical study of the Human Resources Managers' role in small and medium-sized enterprises (SMEs). His current research interests include Human Resources and Outsourcing Processes.

Juan Llopis is a Senior Lecturer in Business Management and Secretary of the Faculty of Economics and Business Studies at the University of Alicante. His Ph.D. dissertation was an analysis of Corporate Culture. His current research lines include Corporate Culture, Human Resources and Technology Management. 
Information Systems Outsourcing: Reasons, Reservations and Success Factors

\begin{abstract}
:
The aim of this paper is to determine the main reasons that lead to Information Systems outsourcing, the reservations that are initially present in front of this kind of contract and the factors considered necessary for the success of outsourcing in the case of Spanish public universities. With this aim, a survey has been made among Information Systems managers in those universities. The results show the possibility of establishing a typology of universities depending on the position they have adopted with respect to outsourcing.
\end{abstract}

\title{
Keywords:
}

Information Systems, Outsourcing, Public Spanish Universities. 


\section{Introduction and Conceptual Background}

Information Systems (IS) Outsourcing means that the physical and/or human resources related to one organisation's Information Technologies (ITs) are supplied and/or administered by an external specialised provider. This situation can be temporary or for an indefinite period and can affect all the IS of the client-firm or only a part of it. It can include data centers, wide area networks, applications development and maintenance functions, end user computing and business processing (Cardinali, 1998). This type of service became very popular in the nineties after the success obtained by Eastman Kodak with the externalisation of its ISs. However, IS contracting dates back to the early years of the introduction of this technology in the business world, when it was common for several firms to use the same computer, because of the high financial investment that the purchase of that computer meant. In recent years, outsourcing has been one of the Information Services that has grown the most (Caldwell, 1996; Lacity and Willcocks, 1998; McLellan, Marcolin and Beamish, 1995; Palvia, 1995) and this rising trend is seemingly going to be maintained in the near future.

What is the key for the success of IS outsourcing? Which are the advantages and inconveniences of this kind of IS managenent? The Transaction Cost Theory has proved to be extremely useful for the analysis of decisions related to IS outsourcing; it suggests a set of pros and cons of these services, which is why several authors have applied this theory with that purpose (Ang and Cummings, 1997; Ang and Straub, 1998; Aubert, Rivard and Patry, 1996; Barthélemy, 2001; Buck-Lew, 1992; Grover, Cheon and Teng, 1996; Jurison, 1995; Lacity and Willcoks, 1995). This theory, originally put forward by Williamson (Williamson, 1975), tries to explain the reasons that determine why firms produce specific goods or services internally or contract them outside through a market transaction.

According to Williamson, the costs involved in the production of specific goods or services within an enterprise can be of two kinds: production costs, which include costs related to work, capital and materials, and co-ordination costs, derived from staff 
management and control. If one goes out to the market, co-ordination costs become transaction costs, caused by the need to define, negotiate and ensure that contracts are enforced, and to co-ordinate activities across the borders of the organisation. Other variables completing this theory are the specificity of assets, the degree of uncertainty and the frequency of transactions. The specificity of assets refers to the level of customisation in a transaction; specific goods or services have a high degree of specificity if they require physical or human goods that cannot be used in transactions with other customers. In the case of IS outsourcing, very standardised activities exist, such as hardware maintenance, but others have a high specificity level, among them, IS strategic planning.

The degree of uncertainty is determined by the information loopholes appearing when the time arrives to decide how to acquire specific goods or services, since it becomes very costly or impossible to make a decision based on thorough information. This uncertainty in outsourcing contracts is closely linked with the difficulties involved in measuring these services (Aubert, Rivard and Patry, 1996).

The frequency of transactions refers to the number of times in which the client seeks to start a transaction. In the case of IS outsourcing, the frequency of activities such as systems operation is unlimited, which is why frequency is not an essential factor for this kind of activity. However, in others, like, for example, programming, which occurs punctually in time, frequency is a variable to be born in mind when it comes to externalising this activity.

Following this theory, IS outsourcing is more efficient than insourcing because production costs are lower in the former: the provider obtains scale economies from mass-producing its services and distributing its fixed costs among a great number of end clients. Moreover, his workforce is specialised, he receives discounts when purchasing materials or when dealing with equipment providers. However, transaction costs are higher with outsourcing, since it is less expensive to control inside staff than an outside 
provider (Lacity and Willcocks, 1995), who tends to adopt an opportunistic attitude (Jurison, 1995). Such a behaviour can become less marked with the gradual increase in the number of external providers of the goods or services in question, as competition among them is encouraged. Likewise, with the increased specificity of the services that the firm wants to contract through outsourcing, the uncertainty around the hiring of these services and the frequency with which the contracted services are required, a growing tendency appears to change from outsourcing to the internalisation of IS activities.

According to Lacity \& Willcocks (Lacity and Willcocks, 1995), the unique and distinct characteristics of ITs usually put clients at a disadvantage with respect to IS outsourcing providers, for the following reasons:

1. ITs evolve so fast that there is a high degree of uncertainty involved in any decisions related to outsourcing.

2. ITs are present in all business functions. This is why knowing the idiosyncrasy of the organisation becomes necessary in order to carry out many IT activities.

3. The costs involved in changing from one IT provider to another are very high, which makes it complicated to encourage competition as a way of discouraging the provider from being opportunistic.

4. Clients often lack experience in signing outsourcing contracts. This is not the case for the provider. As a result of this information dissymmetry, providers are in a much better position in order to favour their own interests.

Previous works have dealt with the study of the reasons that most often lead to IS outsourcing, and also treated the causes that make organisations be initially reluctant to take this decision and, finally, tried to identify the key factors for success in an outsourcing policy. The following reasons have been identified to encourage outsourcing: saving money in IS staff costs or technology-related costs, the increased flexibility in the IS department, the approach adopted by the IS department in relation with its most strategic problems, externalising routine activities, and even promoting 
the enterprise's more specific focus on its business, thus minimising IT problems. Other reasons for the use of outsourcing include improving IS service quality through access to specialised services, facilitating the access to highly-qualified staff and making it easier to have state-of-the-art technology available, passing the risk of equipment obsolescence on to the service provider, having alternatives to the internal IS, etc. (Baldwin, Irani and Love, 2001; Dekleva, 1994; Jones, 1997; Lacity and Hirschheim, 1993a; Lacity and Hirschheim, 1999; McFarlan and Nolan, 1995; McLellan, Marcolin and Beamish, 1995; Tayntor, 2001; Willcocks, Lacity and Fitzgerald, 1995).

In contrast, the following reasons are pointed out, among others, as sources of reluctance to use outsourcing: potential security problems involved in the service, the qualification of the staff working for the provider, the unclear relation between costs and benefits involved in this decision, the possible opposition of the enterprise's own IS staff, the excessively strong dependence on the provider, the provider's incapacity to adapt to new technologies, the fact that the decision is irreversible once it has been made, the hidden costs that may be incurred in the contract, or the loss of basic knowledge in the client-organisation (Akomode, Lees and Irgens, 1998; Dué, 1992; Earl, 1996; Fried, 1995; King and Mahotra, 2000; Meyer, 1994; Palvia, 1995; Shepherd, 1999; Willcocks, Fitzgerald and Lacity, 1996; Udo, 2000).

This analysis would be even more complete if we paid attention to the most important factors affecting the success in this relation, e. g.: the provider should understand the client-organisation's objectives, having a clear idea of what is sought with the use of outsourcing, choosing the right provider, keeping frequent contacts with the provider, drawing up a properly structured outsourcing contract, the top management's support and involvement in outsourcing, specific attention to clients' problems or good value for money; all these topics have been treated, among others, by Chen and Lin (1998), Jones (1997), Lacity and Hirschheim (1993b), Lacity and Willcocks (1998), Lee (2001), McFarlan and Nolan (1995), Martinsons (1993), Saunders, Gebelt and $\mathrm{Hu}$ (1997), and Willcocks, Fitzgerald and Feeny (1995). 
Considering the special importance that choosing a suitable provider may have as a success factor, various works try to find out which factors are held as the most important when it comes to selecting a provider, such as his references or reputation, his solvency or stability, his range of resources, cultural proximity respect to the client, the quality or the price (Collins and Millen, 1995; Heeks et al., 2001; Perry and Devinney, 1997; Shepherd, 1999).

As we can see, several reasons appear both for and against IS outsourcing. This paper aims at exploring these reasons as well as the factors that are considered to be basic for the success of an outsourcing relation, in the specific case of Spanish public universities. Taking this whole set of factors into account, we are going to try and establish a taxonomy of universities. With this purpose in mind, some brief comments will be offered about the population under analysis (Spanish public universities), in order to justify their choice. Finally, a presentation will be made of the methodology, along with the results and conclusions drawn from this empirical study.

\section{The Population under Analysis}

As we have just mentioned, the population under examination is formed by Spanish public universities, which amount to 47 in all. The underlying interest in the choice of these organisations as a reference centre for the study of outsourcing is threefold:

- Universities are information-intensive organisations, since their main objective is to create and spread knowledge. This is why, in theory, ISs are essential for them. Although IS services are, above all, in charge of the application of ISs to management, they also often dedicate their attention to other aspects related to the implementation of ITs in universities; for example, they coordinate computer rooms for teaching or train teaching staff as well as other staff responsible for administrative and service tasks. In short, we find ourselves in front of a very complex type of IS department. 
- Very few studies on IS management practices have been carried out in these organisations, in fact, there are no previous studies on the use of outsourcing in universities. Considering the budget pressures these institutions usually have to face, IS outsourcing is, at first sight, an efficient alternative in order to restrict costs.

- Being lecturers and researchers, our connections with the Spanish public university system make us to reflect on how these services are managed in the organisation we work for.

Spanish public universities have gone through a process of deep change in recent years, particularly for three reasons. Firstly, they have expanded considerably in quantitative terms, to the extent that we can say that there is one university in almost every province. Secondly, their services are increasingly complex, since the offer has been enlarged (master's as well as other post-graduate courses, collaboration schemes with enterprises, university-based institutes, virtual university systems, and so on). Thirdly, universities seek to reach a growing autonomy, both academically and as regards their statutes and ruling capacity, their finances or resource management and, finally, their capacity to select and promote teaching staff. Other countries have experienced similar transformations in their universities, though for longer periods of time, which has enabled them to assume better the new challenges this institution has to face (Vallés, 1996).

An outstanding feature in the Spanish public university organisation is its peculiar management system, headed by the figure of the Rector with the support of the General Manager, who together with vice-rectors and vice-managers constitute what we could call, in business terms, the Top Management. The Rector is a Professor from the University elected in a vote, from whom, apart from his proven teaching and researching capacity, no special management skills are expected or demanded (Muruzábal Lerga, 1995). However, he is at the top of an organisation which handles budgets of billions of pesetas and has thousands of workers, he is the "body" executing the decisions of the 
other governing bodies and the representative of the institution for external relations. The General Manager is appointed by the Rector and occupies a position of trust; he is in charge of managing economic and administrative services. The creation of this figure was one of the best contributions made by the Ley de Reforma Universitaria -L.R.U.(The University Reform Act), since it was understood that a professional manager had to be in charge of the direct technical responsibility for support services (financial, logistic and administrative ones).

As is specifically pointed out in the L.R.U., the university is not the patrimony of the university community, instead it is a public service in which the society's general interests must be attended to. This is why, in recent years, society has put universities under pressure asking them to account for the results of their management; thus, many people demand some kind of monitoring of the way in which services are delivered and developed as well as an assessment of their quality (Ordóñez, 2000; Ortí Lahoz, 1995). Along with this social pressure, Spanish public universities are traditionally subject to budget restrictions (Ortí Lahoz, 1995). Their own income basically comes from university fees, which represent only 20 to $25 \%$ of their annual budgets. This is why it needs funding from the Government.

\section{Methodology}

In order to deal with the empirical work, we have carried out a survey in the universities under analysis[1]. There is a disadvantage we have to face; namely, the fact that there are hardly any field studies on IS outsourcing in general, since the most common works about these matters describe the experiences of specific firms; in other words, they are case studies.

Taking the literature about this topic as our basis, we elaborated the first draft of the questionnaire. We discussed this draft with the head of the University of Alicante's Data Processing Centre[2], who suggested various modifications that helped to enrich the questionnaire. After making the appropriate modifications, a parcel was sent to all 
47 Spanish public universities, containing the final questionnaire and a presentation letter for the study, in which its objectives were explained; the recipients were asked to fill in the questionnaire and guarantees were given that their answers would be anonymous. The parcel also included a stamped addressed envelope so that the filled-in questionnaire could be returned. The questionnaire recipients were the heads of ISs in the different universities, whose names and addresses had been collected after a laborious search through the webpages of each university [3].

We followed the recommendations made in previous studies on this topic for the interviewees' participation to be maximised (Grover, Cheon and Teng, 1994). For this reason, after sending the questionnaire, in December 1999, successive calls were made to remind the interviewees to send us back the filled-in questionnaires. Thus, in January 2000, an e-mail was sent to all those who had not answered by that date, in which we wished them a happy new year, and added the questionnaire on an electronic format, asking for their collaboration once again. One month later, a postcard with a local motif was sent to those that had fallen behind, in which, yet again, we insisted on the importance of their collaboration. Later, in March, we phoned those who still had not answered and begged them to participate in our work. Because the interviewed population was limited, we needed as many answers as possible for the results to be significant, which is why we made all those reminder calls requesting participation.

Although we addressed the 47 individuals that form the universe of this survey, we only obtained 35 valid cases. This means we work with a global error level of \pm 1.2 . These 35 cases account for $74.5 \%$ of the universities, a high percentage, if we compare it to the answer ratios of other works on outsourcing (25\% in that by Collins and Millen (1995), 17\% in that by Arnett and Jones (1994), 19\% in that by Grover, Cheon and Teng (1994) and $20 \%$ in that by Corbett (1994), although we must note that the population under analysis in the above-mentioned works was much larger than ours.

\section{Results}


The data obtained in the survey have been treated using the SPSS 9.0 software for Windows.

\section{Profile of Universities and Interviewees}

take in Table I

The interviewed organisations represent the diversity of Spanish university institutions in terms of their age: from those that are over one century old, which account for $17.1 \%$, to the most modern ones created in the 90's (see Table I); the latter are the most numerous, since they account for $31.4 \%$ of the answers obtained, a piece of information that confirms the expansion the Spanish university system has experienced in recent years.

As regards size, most of them (42.9\%) have between 25,000 and 50,000 registered students, while the percentage corresponding to those with less than 25,000 students is lower (37.1\%), and only very few have more than 50,000 students $(17.1 \%)$. Additional data that can be revealing about dimensions have to do with staff. The figures for teaching and research staff in an average university amount to 1,659 people, with a further 701 people dedicated to administration and service tasks. The IS service is included in the second group and counts on 31 workers on average at each university.

The figures above tell us that we find ourselves in front of very complex organisations, considering the number of workers and clients (students) they have.

\section{take in Table II}

As for the IS manager (Table II), to whom the survey is addressed, he has had that job for 5 years on average, and his age ranges between 29 and 57 years old, the average being 41 . Most of these responsibility posts are occupied by males, and in terms of the university organisation chart, they are under the authority of the General Manager, of one Vice-Rector, or both.

\section{Outsourced Activities}


take in Table III

The specific activities of IS services are represented on Table III, which shows the percentage of outsourcing of those activities in the universities being analysed. As can be seen, hardware maintenance, followed by programming, software maintenance, applications analysis and staff and/or user training are the most often outsourced activities. However, services such as systems implementation, network services, support to end users, security and system operations, are not usually contracted with an external provider.

Anyhow, except for hardware maintenance, universities do not externalise a large proportion of their IS activities. Instead, they opt for a kind of outsourcing that we can call selective[4]. Furthermore, the tasks that are most often contracted with external providers are easily justified; on the one hand, it is customary for hardware and software maintenance to be carried out by providers as an additional updating service. On the other hand, when working peaks arise in these activities as a result of the development of new systems, it is also common to contract the most monotonous part of the development externally, for example, programming. Hence, we can say that Spanish universities do not stand out as organisations outsourcing a large proportion of their IS activities.

\section{Reasons for Outsourcing}

take in Table IV

Table IV shows the reasons that were most relevant when the time arrived to externalise IS activities in universities; they materialised in 8 variables. The explanation for each variable appears in the first column, along with their respective codes. The second column shows the number of interviewees that mentioned each reason and the percentage of interviewees that gave each one of them. The addition of percentages equals 300 , since each interviewee pointed out those three reasons that, in their view, were the most influential in the outsourcing process. 
As we can see, saving staff costs is the reason that most clearly fosters the use of outsourcing (68.6\% of the answers), followed closely by the increased flexibility of the IS service, after all, outsourcing makes it possible to cover the increases of work without needing to change the structure of the IS department. Although this is also a clearly decisive feature, a much smaller proportion of universities (40\%) mention the possibility that outsourcing offers to focus more specifically on IS strategic problems, since, as pointed out by $37.1 \%$ of the interviewees, the most monotonous and troublesome tasks of this service can be externalised.

The reasons that are least important in outsourcing are making easier the access to new technologies and preventing equipment obsolescence (mentioned by only $11.4 \%$ of the interviewees); also little attention is paid to the search for new alternatives to the internal IS $(17.1 \%)$, or to IS quality enhancement (28.6\% of the universities). Saving money in technology-related costs, mentioned by over a third of the interviewees, is the fifth most important reason for outsourcing, curiously with much less value than saving in staff costs.

If we look at the set of reasons mentioned and distinguish the four most important ones as opposed to the four least important, we can conclude that externalisation has come to solve problems related to staffing and organisational design (staff costs and activity re-structuring) through a stronger emphasis on strategic matters and the transfer of routine work to external providers. However, firms do not use outsourcing so much in order to solve technical problems, such as saving in technologyrelated costs, the access to new technologies, preventing technological obsolescence, having alternatives available to the internal IS or improving service quality in the IS.

\section{Reservations about Outsourcing}

take in Table V

As regards the causes of reservations when it comes to facing a decision to use outsourcing, the results are shown in Table V, which has a similar structure to that of 
Table IV. We check that the problem most important about outsourcing is the excessive dependence the customer feels from the provider of these services, since that provider is usually going to be in charge of activities that were previously carried out inside the IS department itself. This is by far the most often mentioned cause of reluctance to outsource, pointed out by $68.6 \%$ of the universities. Fear is also generated by the potential incapacitation of IS departments, because they might lose basic knowledge or infrastructure when part of their activities is externalised (a question that is closely related to the dependence on the provider that is generated) and that providers should not be serious in complying with the contracts signed (as is pointed out in $37.1 \%$ and in $34.3 \%$ of the cases, respectively). One third of the universities were initially distrustful of the qualification of the staff working for the enterprise that provided outsourcing services, and likewise, did not clearly perceive the relation between the benefits to be obtained through these services and the costs they generated (as is pointed out in $31.4 \%$ of the cases).

Among the causes of reservations that interviewees gave less importance to are, on the one hand, that the provider should not be able to adapt to new technologies, since only $8.6 \%$ of the interviewees were afraid that this should happen. Likewise, it seems that the decision to externalise is not seen as something irreversible, or as something that generates security problems associated with IS services, a circumstance that could be due to the introduction of a strange element into university ISs, causing lack of confidentiality in the information. We can conclude that outsourcing does not solve problems that are first and foremost technical ones, but those related to staff management and, in parallel, that the reservations about these services are not derived from potential technological problems either.

Although it is usually argued that outsourcing services generate unforeseen, hidden costs, above all if the contract is not properly detailed, this is not an important cause of reluctance, nor is the possible opposition on the part of the internal staff 
(pointed out by $28.6 \%$ of the interviewees), although, in fact, this practice may put some jobs in danger.

\section{The Success of Outsourcing}

take in Table VI

Table VI reflects the importance universities interviewed assign to success factors in an outsourcing relation. The most important factor is, by far, that the provider should be able to understand the client's objectives and goals, as was pointed out by $74.3 \%$ of the interviewees. Hence, we infer that outsourcing is not a standard service, but implies a deep relation between client and provider, so that the latter can solve the former's specific problems.

Many interviewees (42.8\%) think that success depends on the university heads' willingness to support and become involved in this kind of service, this being an essential aspect in all the processes leading to the introduction of new technologies or new information services into organisations. Other success factors follow in order of relevance, namely, how to choose the right provider, holding frequent client-provider meetings, and the need for the latter to consider carefully the former's problems. We should highlight that the last two factors are somehow redundant with the factor mentioned in first place and bear many resemblances with it .

Despite the importance literature on this topic gives to the fact that outsourcing contracts must be detailed, thorough, and that a lot of attention must be paid to the small print in those contracts (Globerman and Vining, 1996; Jones, 1997; Judenberg, 1994; Richmond, 1992; Willcocks, Lacity and Fitzgerald, 1995), this aspect has been ranked as the sixth success factor, though it must be remembered that a fourth of the universities consider this factor to be important. The last matters of interest that can lead to success in this relation refer to the need of a clear notion about what is intended and to the possibility of achieving a good value for money relation. 


\title{
The Outsourcing Provider
}

\author{
take in Table VII
}

As we have just seen, many success factors in outsourcing depend on the provider of this type of services. This is why it becomes interesting to focus more to the characteristics of this provider. Table VII reflects what is demanded from the outsourcing service provider. Service quality is unarguably the most highly appreciated feature, much more than price (74.3\% of the answers compared to $28.6 \%$ ). These results are appealing if we bear in mind the financial problems universities interviewed usually have to face, as we explained above. On the other hand, when choosing the provider great significance is assigned to the role of cultural and personal matters in an outsourcing relation; hence the vital importance of other factors, such as the record of previous relations between that provider and the specific customer $(51.4 \%$ of the interviewees mentioned this factor) or their cultural proximity (pointed out by $37.1 \%$ of the interviewees). We must highlight that the fifth most important factor in the choice of a provider (it was indeed mentioned by $34.4 \%$ of the universities) is based on the references and reputation of the provider in other universities, a factor that can also be classified as cultural, as it is impossible to measured it objectively.

Exactly as seen on Table VI, the characteristics of the outsourcing contract, like, for example, its flexibility, do not seem to be very relevant for universities, since this factor is ranked seventh in importance in the provider selection process. The last place in this classification in order of relevance is occupied by the range of services offered by the provider.

As a summary of Table VII, we can say that, except for quality, which is the most important aspect when choosing a provider, the other features that are most often sought in the figure of the provider have to do with cultural and personal matters.

\section{A Typology of Universities}


The variables analysed on Tables IV to VII could give rise to a typology of universities according to the reasons each of them has to use outsourcing, to the fears and reservations they have about this alternative, and finally, to what they consider success factors in this relation. A Cluster Analysis[5] has been carried out in order to check if such a typology can be effectively established. We have had to avoid variables corresponding to Table VII in this analysis so that coherent results could appear from the logical point of view. For this reason, we have used 26 variables: 8 of them drawn from Table IV, 10 from Table V and 8 from Table VI.

The Cluster Analysis has been carried out with the Hierarchical Conglomerates Analysis Module of the SPSS 9.0 software. That module gives us information about the conglomeration record, which is a summary of the way the different groups or clusters have progressively been formed, as well as the dendrogram, which represents group formation graphically (See Appendix 2).

\section{take in Table VIII}

Applying of this analysis has enabled us to discover three clusters or types of universities[6] (Table VIII). Universities located in the first cluster declare that the reasons for outsourcing (items XIVc, $\mathrm{d}$ and $\mathrm{f}$ ) are based on the IS department's improvement, since, apart from improving service quality and increasing flexibility, they focus on strategic matters. Reservations among this group (items XVe, g and j) are based on the fear that the department should lose some of its capacity, because, in their view, basic knowledge or skills can be lost, and an excessive dependence from the provider may arise, all of which would turn outsourcing into an irreversible decision. Universities in this group think that the success of outsourcing depends on the customers themselves rather than on the provider (items XVIb, c and f); in this sense, the customer must have a clear idea of what is intended with the use of outsourcing, choose the right provider as well as obtain the support and involvement of the heads of the university's main ruling bodies. Considering the characteristics mentioned, we can call the universities grouped together in this cluster perfectionist. 
In the second group are located the universities that we call hesitant with respect to outsourcing, since their reasons (items XIVe, $g$ and $h$ ) are based, above all, on the lack of concern for a function that may be problematic, i.e., a function that involves routine, troublesome tasks, and requires being permanently up to date with new technologies, which, in turn, quickly become obsolete, all of which makes it convenient to look for alternatives to the internal IS. However, the reservations among this group (items XVa, c, f, h and i) lie in the lack of confidence in externalisation, since they think outsourcing may provoke security problems for the IS department. They cannot see a clear relation between the costs and benefits derived from outsourcing, fear the existence of hidden costs in outsourcing contracts and are distrustful of the potential failures on the part of the provider to comply with the contract, as well as of the providers' capacity to adapt to new technologies. These universities believe that the success of outsourcing (items XVIe and h) does not depend on the customer or the provider, but basically on signing a properly drawn-up contract, in which a good value for money is achieved.

As regards the third group, it is formed by universities that we can call costreducing, as the main reason for outsourcing lies in cost saving, both in terms of staff and concerning technology (items XIVa and b). Reservations about externalisation in this group (items $\mathrm{XVb}$ and d) are based on staff problems, which can arise from both the qualification of the staff working for the provider, about which there are doubts, and from the possible opposition on the part of the staff working for the IS service itself. Concerning the success of outsourcing (items XVIa, $\mathrm{d}$ and $\mathrm{g}$ ), universities included in this cluster think it depends on the provider of these services, since the provider must understand clients' objectives and goals by keeping frequent contacts with those clients as well, and thus pay due attention to their specific problems.

\section{Summary and Conclusions}

IS outsourcing is a useful managerial practice in the IS departments of Spanish public universities because it can help control costs, above all, in the activities that are 
more monotonous. However, these universities do not stand out as organisations externalising a large proportion of their IT activities. They especially use outsourcing for hardware and software maintenance and programming, that is, for the activities considered to have a low specificity level.

The Transaction Cost Theory has been helpful to us as a basis to check the reasons for and against IS outsourcing in Spanish public universities. On the one hand, this alternative is first and foremost used to solve problems related to staff management, as well as organisational design, in IS departments, but not to compensate for the lack of technical resources. In other words, the aim is to reduce coordination costs rather than those associated with production. On the other hand, the basic problem about outsourcing is the excessive dependence the customer feels from the provider of these services, along with the potential incapacitation of the IS department, as a result of the loss of basic infrastructure, knowledge or skills. Therefore, an underlying fear exists that transaction costs may increase, as a result of a opportunistic behaviour on the part of the provider that could leave the client disarmed.

Universities interviewed think that the most important element for an outsourcing relation to be successful is that the provider should understand the client's objectives and goals. This is so because outsourcing is not a standard service, but a deep relation that must be established between the parties involved.

Depending on the reasons that lead to the use of outsourcing, the causes of reluctance to outsource and the factors considered to be important for the success of this relation, we have identified three types of universities in a classification that has been made through the application of a cluster analysis.

- The first group is formed by those universities that have a perfectionist attitude regarding their IS. These are the ones that use outsourcing in order to improve their IS departments; they are afraid that their capacity might be reduced after 
externalising some activities and believe that the success of the outsourcing relation depends on the clients using these services.

- In the second group are included universities with a hesitant position as far as outsourcing is concerned. These are the ones which resort to this alternative in order to get rid of IS-related troublesome tasks, though they do not have a clear idea of what they will obtain from externalisation. Universities in this group are characterised by the strong belief that a properly drawn-up contract is essential for the success of outsourcing.

- Those universities which use outsourcing mainly to cut costs form the third cluster. Above all, they find staff-related problems in a contract of this kind and think that the success of outsourcing depends on the provider of these services.

It would be advisable for most organizations to bear resemblances with the first group, since outsourcing is, in this case, an alternative for IS improvement. Organizations of this kind are aware that the lack of internal experience and the excesive dependence on the provider can be undesirable consequences of outsourcing that can appear in the medium and long run (Smith, Mitra and Narasimhan, 1998). They also know that it is the service client himself that can do the most to help such a relation work; first of all, the client must clearly understand the objectives sought through the use of outsourcing (Clarck, Zmud and Mc Cray, 1995).

Finally, we must refer to the limitations of this paper, since it focuses on the study of IS outsourcing in a specific type of organisation, more precisely, Spanish public universities. This is why the results can only be cautiously extrapolated to other types of organisations. Another limitation derived from having chosen Spanish public universities as our object of study consists in the small population size, only 47 cases, and, thus, the small sample size. This is why the results offered in this study have confined themselves to descriptive stadistics and to the carrying-out of a cluster analysis exclusively on the basis of its dendogram, and have given up the possibility of more complex statistical tests. 
Other limitations of this study come from the way in which the information was obtained, both regarding the questions asked to the interviewees and the interviewees themselves. Firstly, questions 14, 15, 16 and 17 (see Apendix 1) refer to the three most influential reasons, the three main causes for reservations, the three most important factors to be succesful and the three most important factors to select an IS service provider in an outsourcing process. We acknowledge that the richness of the findings can be limited by this kind of questions, but we have used them because they are easy to answer, and we wanted to maximise the answer ratio. Secondly, the interviewees have different profiles in terms of knowledge level, experience, and so on. This is an inherent problem in most surveys. Future research could analyse information similar to that in our study concerning to various IS Manager profiles.

In spite of these limitations we hope this paper can be useful to highlight the key pros and cons in the process of IS outsourcing.

\section{Notes}

[1] This empirical research work is a part of a more comprehensive study that covers various aspects related to IS outsourcing in Spanish public universities.

[2] This is Mr. Juan Manuel Aparicio, to whom we are thankful for his collaboration.

[3] The final questionnaire includes 24 questions, of which only 7 were used in the present study. Appendix 1 shows these 7 questions with its original numbers, so that those numbers can coincide with the codes on the tables.

[4] Outsourcing is called 'selective' when only some IS activities are externalised, namely those in which the provider offers clear advantages (Jurison, 1995). Selective outsourcing succeeds in meeting the client's needs and minimises the risks involved in total outsourcing (Lacity, Willcocks and Feeny, 1996).

[5] The cluster analysis is used to classify a large population into a small number of mutually exclusive, exhaustive groups, according to the similarities and differences of the existing profiles among the different elements forming that population. The main limitation in such an analysis is the absence of analytical solutions for the results, which 
forces the researcher to trust his own judgement when determining the number of resulting groups. Two broad categories are distinguished in cluster analysis: hierarchical and non-hierarchical methods. In this study, we have applied a hierarchical method (the average linkage method between groups) which is one of the most often used and is, in fact, the method that functions by default in SPSS.

[6] The way to determine these three clusters has basically consisted in checking how the dendrogram breaks down into three groups. This method is very often used in other studies (Ketchen and Shook, 1996).

\section{References}

Akomode, O.J.; Lees, B. and Irgens, Ch. (1998), "Constructing Customised Models and Providing Information to Support IS Outsourcing Decisions", Logistics Information Management, Vol 11 No 2, pp. 114-127.

Ang, S. and Cummings, L.L. (1997), "Strategic Response to Institutional Influences on Information Systems Outsourcing", Organization Science, Vol 8 No 3, pp. 235-256.

Ang, S. and Straub, D. (1998), "Production and Transaction Economies and IS Outsourcing: A Study of the U.S. Bank Industry”, MIS Quarterly, Vol 22, No 4, pp. 535-552. Arnett, K.P. and Jones, M.C. (1994), "Firms that Choose Outsourcing: A Profile", Information \& Management, Vol 26 No 4, pp.179-188.

Aubert, B.A.; Rivard, S. and Patry, M. A. (1996), "Transaction Cost Approach to Outsourcing Behavior: Some Empirical Evidence”, Information \& Management, Vol 30 No 2, pp. 51-64.

Baldwin, LP; Irani, Z. and Love, P. (2001), “Outsourcing Information Systems: Drawing Lessons from a Banking Case Study", European Journal of Information Systems, Vol 10 No 1, pp. $15-24$.

Barthélemy, J. (2001), “The Hidden Cost of IT Outsourcing”, MIT Sloan Management Review, Vol 42 No 3, pp. 60-69.

Buck-Lew, M. (1992), “To Outsource or Not?”, International Journal of Information Management, Vol 12, pp. 3-20. 
Caldwell, B. (1996), “The New Outsourcing Partnership”, Information Week, No 585, pp. $50-64$.

Cardinali, R. (1998), "Viewpoint: death of the knowledge worker", Logistic Information Management, Vol 11 No 3, pp. 156-159.

Chen, Q. and Lin, B. (1998), "Global Outsourcing and its Managerial Implications", Human Systems Management, Vol 17 No 2, pp. 109-114.

Clark, T.D.; Zmud, R.W. and McCray, G.E. (1995), "The Outsourcing of Information Services: Transforming the Nature of Business in the Information Industry", Journal of Information Technology, Vol 10, pp. 221-237.

Collins, J.S. and Millen, R.A. (1995), "Information Systems Outsourcing by Large American Industrial Firms: Choices and Impacts", Information Resources Management Journal, Vol 8 No 1, pp. 5-13.

Corbett, M.F. (1994), “Outsourcing and the New IT Executive. A Trends Report", Information Systems Management, Vol 11 No 4, pp. 19-22.

Dekleva, S.M. (1994), “CFOs, CIOs and Outsourcing”, Computerworld, Vol 28 No 20, pp. 96.

Dué, R.T. (1992), “The Real Cost of Outsourcing”, Information Systems Management, Vol 9 No 1, pp. 78-81.

Earl, M.J. (1996), “The Risk of Outsourcing IT”, Sloan Management Review, Vol 37 No 3, pp. 26-32.

Fried, L. (1995), Managing Information Technology in Turbulent Times, Wiley, New York. Globerman, S. and Vining, A.R. (1996), “A Framework for Evaluating the Government Contracting-out Decision with an Application to Information Technology", Public Administration Review, Vol 56 No 6, pp. 577-586.

Grover, V.; Cheon, M.J. and Teng, T.C. (1994), “A Descriptive Study on the Outsourcing of Information Systems Functions", Information \& Management, Vol 27 No 1, pp. 33-44.

Grover, V.; Cheon, M.J. and Teng, T.C. (1996), "The Effect of Service Quality and Partnership on the Outsourcing of Information Systems Functions", Journal of Management Information Systems, Vol 12 No 4, pp. 89-116. 
Heeks, R. et al. (2001), "Synching or Sinking: Global Software Outsourcing Relationships", IEEE Software, Vol 18 No 2, pp. 54-60.

Jones, W. (1997), “Outsourcing Basics”, Information Systems Management, Vol 14 No 1, pp. 66-69.

Judenberg, J. (1994), “Applications Maintenance Outsourcing. An Alternative to Total Outsourcing", Information Systems Management, Vol 11 No 4, pp. 34-38.

Jurison, J. (1995), “The Role of Risk and Return in Information Technology Outsourcing Decisions”, Journal of Information Technology, No 10, pp. 239-247.

Ketchen, D.J. and Shook, C.L. (1996), "The Applications of Cluster Analysis in Strategic Management Research: and Analysis and Critique”, Strategic Management Journal, Vol 17 No 6, pp. 441-458.

King, W.R. and Malhotra, Y. (2000), “Developing a Framework for analyzing IS Outsourcing”, Information \& Management, Vol 37 No 6, pp. 323-334.

Lacity, M. and Hirschheim, R. (1993a), "Implementing Information Systems Outsourcing: Key Issues and Experiences of an Early Adopter", Journal of General Management, Vol 19 No 1, pp. 17-31.

Lacity, M. and Hirschheim, R. (1993b), “The Information Systems Outsourcing Bandwagon”, Sloan Management Review, Vol 35 No 1, pp. 73-86.

Lacity, M.C. and Hirschheim, R. (1999), "Information Technology Outsourcing: What Problems are we Trying to Solve?", in Currie, N.L. and Galliers, B. (Ed.), Rethinking Management Information Systems, Oxford University Press, Oxford, pp. 326-360.

Lacity, M. and Willcocks, L. (1995), “Interpreting Information Technology Sourcing Decisions from a Transaction Cost Perspective: Findings and Critique”, Accounting, Management \& Information Technology, Vol 5 No 3/4, pp. 203-244.

Lacity, M. and Willcocks, L. (1998), “An Empirical Investigation of Information Technology Sourcing Practices: Lessons from Experience”, MIS Quarterly, Vol 22 No 3, pp. 363-408.

Lacity, M.C.; Willcocks, L.P. and Feeny, D.F. (1996), "The Value of Selective Sourcing", Sloan Management Review, Vol 37 No 3, pp. 13-25. 
Lee, J-N. (2001), “The Impact of Knowledge Sharing, Organizational Capability and Partnership Quality on IS Outsourcing Success", Information \& Management, Vol 38 No 5, pp. 323-335.

Martinsons, M.G. (1993), “Outsourcing Information Systems: A Strategic Partnership with Risk", Long Range Planning, Vol 26 No 3, pp. 18-25.

McFarlan, F.W. and Nolan, R.L. (1995), "How to Manage an IT Outsourcing Alliance", Sloan Management Review, Vol 36 No 2, pp. 8-23.

McLellan, K.; Marcolin, B. and Beamish, P. (1995), "Financial and Strategic Motivations behind IS Outsourcing”, Journal of Information Technology, No 10, pp. 299-321.

Meyer, N.D. (1994), "A Sensible Approach to Outsourcing. The Economic Fundamentals", Information Systems Management, Vol 11 No 4, pp. 23-27.

Muruzábal Lerga, J. (1995), “Autonomía y Gestión Universitaria”, Auditoría Pública, No 3, pp. 12-15.

Ordóñez, S. (2000), “¿Qué Universidad Queremos?”, Saber, No 8, pp. 16-20.

Ortí Lahoz, A. (1995), "La Permanente Insuficiencia del Presupuesto Universitario", Auditoría Pública, No 3, pp. 32-35.

Palvia, P.C. (1995), “A Dialectic View of Information Systems Outsourcing: Pros and Cons", Information \& Management, Vol 29 No 5, pp. 265-275.

Perry, W. and Devinney, S. (1997), "Achieving Quality Outsourcing", Information Systems Management, Vol 14 No 2, pp. 23-26.

Richmond, W.B. and Whinston, A.B. (1992), "Incomplete Contracting Issues in Information Systems Development Outsourcing”, Decision Support Systems, Vol 8 No 5, pp. 459-477.

Saunders, C.; Gebelt, M. and Hu, Q. (1997), "Achieving Success in Information Systems Outsourcing", California Management Review, Vol 39 No 2, pp. 63-79.

Shepherd, A. (1999), "Outsourcing IT in a Changing World", European Management Journal, Vol 17 No 1, pp. 64-84.

Smith, M.A.; Mitra, S. and Narasimhan, S. (1998), "Information Systems Outsourcing: A Study of Pre-Event Firm Characteristics", Journal of Management Information Systems, Vol 15 No 2, pp. 61-93. 
Tayntor, Ch.B. (2001), "A Practical Guide to Staff Augmentation and Outsourcing”, Information Systems Management, Vol 18 No 1, pp. 84-91.

Udo, G.G. (2000), “Using Analytic Hierarchy Process to Analyze the Information Technology Outsourcing Decision", Industrial Management \& Data Systems, Vol 100 No 9, pp. 421-429.

Vallés, J.M. (1996), “Gobierno Universitario: Entre la Autogestión Estamental y la Responsabilidad Social”, Gestión y Análisis de Administraciones Públicas, No 5-6, pp. 59-67.

Willcocks, L.; Fitzgerald, G. and Feeny, D. (1995), “Outsourcing IT: The Strategic Implications", Long Range Planning, Vol 28 No 5, pp. 59-70.

Willcocks, L.; Fitzgerald, G. and Lacity, M, (1996), “To Outsource or not? Recent Research on Economics and Evaluation Practice", European Journal of Information Systems, No 5, pp. 143-160.

Willcocks, L.; Lacity, M. and Fitzgerald, G. (1995), "Information Technology Outsourcing in Europe and in the USA: Assessment Issues", International Journal of Information Management, Vol 15 No 5, pp. 333-351.

Williamson, O.E. (1975), Markets and Hierarchies. Analysis and Antitrust Implications, The Free Press, New York.

\section{Appendix 1: Questionnaire}

1. Univerty Profile.

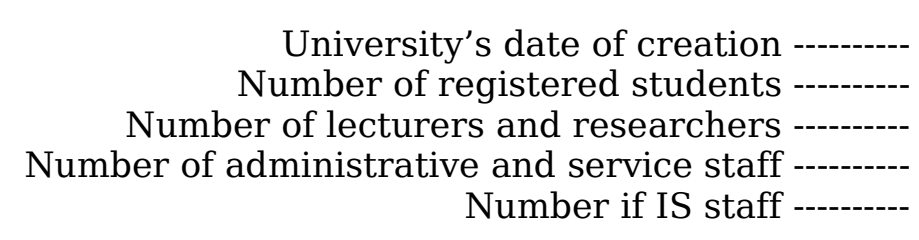

2. Univerty IS Manager Profile.

Time during which the interviewee has held the current post 
8. Of the following IS service activities, give a number corresponding to the percentage which is approximately carried out by external providers.

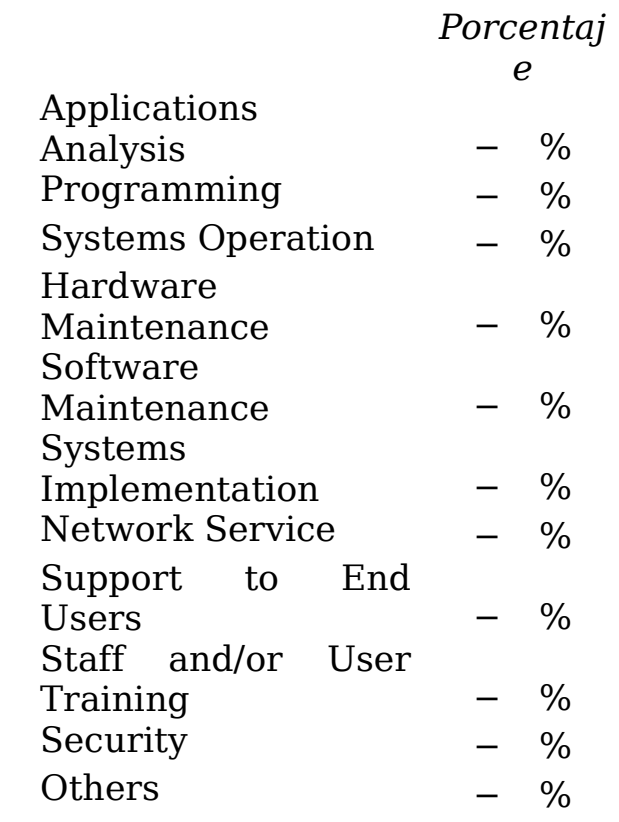

14. Put a tick on the three most influential reasons when it comes to deciding the externalization of part of the IS.

- Staff cost saving

- Technology cost saving

- Increased flexibility of the IS department

- Focus on IS strategic issues

- Elimination of troublesome, everyday problems

- Improved IS quality

- Increased access to new technology and reduced tecnological obsolescence risk

- Providing alternatives to in-house IS

- Others

15. Put a tick on the three main causes for reservations appearing when the time arrived to decide whether to externalise or not.

- Security issues

- Qualification of provider's staff

- Costs/benefits unclear

- A posible opposition from our IS staff

- A great dependence on the provider

- Incapacity to adapt to new technologies

- Irreversibility of the outsourcing decision

- The provider does not comply with the contract

- Hidden costs in the contract

- Loss of critical skills and competences

- Others

16. Put a tick on the three factors considered to be most important for and outsourcing process to be successful. 
- The provider must understand the client's objectives

- To know what is intended with the use of outsourcing

- Choosing the right provider

- Frequency of client-provider contacts

- To make a properly drawn-up contract

- The top management's support and involvement

- To pay careful attention to the client's specific problems

- A good value for money relation

- Others

17. Put a tick on the three factors regarded as most important when it comes to select an IS service provider

- Service quality

- The price

- The provider's reports and reputation at other universities

- Contract flexibility

- The provider's resources

- Cultural proximity between client and provider

- The provider's solvency and stability

- Previous client-provider relations

- Others

\section{Appendix 2: Hierarchical Cluster Analysis}

take in Table IX

take in Figure 1 
TABLE I: UNIVERSITY PROFILE

\begin{tabular}{|c|c|c|c|c|c|}
\hline \multicolumn{2}{|c|}{ Date of Creation } & \multicolumn{4}{|c|}{ Registered Students } \\
\hline \multirow{2}{*}{$\begin{array}{l}\text { More than } \\
\text { century ago } \\
1060 / 1079\end{array}$} & \multirow{2}{*}{$\begin{array}{r}6 \\
(17.1 \%) \\
8 \\
(22.9 \%)\end{array}$} & \multicolumn{2}{|c|}{\begin{tabular}{l|l}
$0-25,000$ & \\
\end{tabular}} & \multicolumn{2}{|r|}{$(37.1 \%)$} \\
\hline & & $25-50,000$ & & 15 & $(42.9 \%)$ \\
\hline 1980/1989 & $\begin{array}{r}3 \\
(8.6 \%)\end{array}$ & $\begin{array}{l}\text { More } \\
\mathbf{5 0 , 0 0 0}\end{array}$ & ian & 6 & $(17.1 \%)$ \\
\hline After 1990 & $\begin{array}{r}11 \\
(31.4 \%)\end{array}$ & No answer & & 1 & \\
\hline No answer & $\begin{array}{r}7 \\
(20.0 \%)\end{array}$ & TOTAL & & 35 & $(100.0 \%)$ \\
\hline TOTAL & $\begin{array}{r}35 \\
(100.0 \%)\end{array}$ & & & & \\
\hline & Minimum & Maximum & Mean & & $\begin{array}{l}\text { Std. } \\
\text { eviation }\end{array}$ \\
\hline $\mathbf{N L R}^{\mathrm{a}}(\mathbf{n}=33)$ & 542 & 3500 & 1659.4 & & 883.5 \\
\hline $\operatorname{NASS}^{b}(n=33)$ & 200 & 1500 & 701.0 & & 379.9 \\
\hline $\operatorname{NISS}^{c}(n=34)$ & 9 & 83 & 31.0 & & 18.3 \\
\hline
\end{tabular}

${ }^{a}$ Number of Lecturers and Researchers.

b Number of Administrative and Service Staff.

${ }^{\mathrm{c}}$ Number of IS Staff.

TABLE II: THE IS UNIVERSITY MANAGER

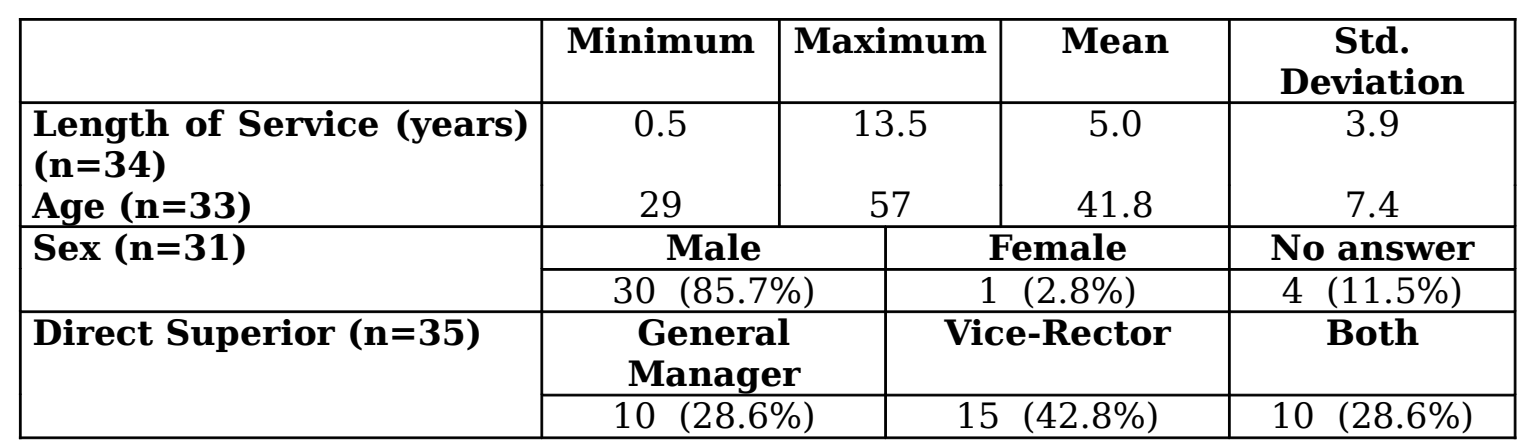

TABLE III: OUTSOURCED IS ACTIVITIES (PERCENTAGES)

\begin{tabular}{|l|c|c|}
\hline \multirow{2}{*}{ IS Activities } & \multicolumn{2}{|c|}{$\begin{array}{c}\text { Outsourcing } \\
\text { Percentages }\end{array}$} \\
\cline { 2 - 3 } & Mean & $\begin{array}{c}\text { Std. } \\
\text { Deviation }\end{array}$ \\
\hline $\begin{array}{l}\text { Hardware Maintenance } \\
\text { Programming }\end{array}$ & 70.1 & 33.7 \\
Software Maintenance & 38.1 & 34.8 \\
$\begin{array}{l}\text { Applications Analysis } \\
\text { Staff and/or User }\end{array}$ & 37.6 & 28.6 \\
Training & 28.0 & 32.9 \\
Systems Implementation & 19.3 & 28.1 \\
Network Service & 15.0 & 21.8 \\
Support to End Users & 4.3 & 20.7 \\
Security Operation & 4.3 & 17.7 \\
Systems Operation & 3.7 & 10.3 \\
\hline
\end{tabular}


TABLE IV: REASONS FOR OUTSOURCING

\begin{tabular}{|l|l|l|}
\hline Code & \multicolumn{1}{|c|}{ Variable } & $\mathrm{N}$ \\
\hline $\mathrm{XIVa}$ & Staff cost saving & 24 \\
$\mathrm{XIVC}$ & Increased flexibility of the IS department & $(68.6 \%)$ \\
$\mathrm{XIVd}$ & Focus on IS strategic issues & 22 \\
& & $(62.8 \%)$ \\
$\mathrm{XIVe}$ & Elimination of troublesome, everyday problems & $(40.0 \%)$ \\
$\mathrm{XIVb}$ & Technology cost saving & 13 \\
$\mathrm{XIVf}$ & Improved IS quality & $(37.1 \%)$ \\
& & 12 \\
$\mathrm{XIVh}$ & Providing alternatives to in-house IS & $(34.3 \%)$ \\
$\mathrm{XIVg}$ & Increased access to new technology and reduced & $(28.6 \%)$ \\
& technological obsolescence risk & 6 \\
& TOTAL & $(17.1 \%)$ \\
\end{tabular}

TABLE V: RESERVATIONS ABOUT OUTSOURCING

\begin{tabular}{|c|c|c|}
\hline $\begin{array}{c}\text { C } \\
\text { ode }\end{array}$ & Variable & \\
\hline $\mathrm{XVe}$ & A great dependence on the provider & \begin{tabular}{|l|}
24 \\
$(68.6 \%)$
\end{tabular} \\
\hline $\mathrm{XVj}$ & Loss of critical skills and competences & $\begin{array}{l}13 \\
(37.1 \%)\end{array}$ \\
\hline $\mathrm{XVh}$ & $\begin{array}{l}\text { The provider does not comply with the } \\
\text { contract }\end{array}$ & $\begin{array}{l}12 \\
(34.3 \%)\end{array}$ \\
\hline $\mathrm{XVb}$ & Qualification of provider's staff & $\begin{array}{l}11 \\
(31.4 \%)\end{array}$ \\
\hline XVc & Costs/benefits unclear & $\begin{array}{l}11 \\
(31.4 \%)\end{array}$ \\
\hline $\mathrm{XVd}$ & A possible opposition from our IS staff & $\begin{array}{l}10 \\
(28.6 \%)\end{array}$ \\
\hline $\mathrm{XVi}$ & Hidden costs in the contract & $\begin{array}{l}8 \\
(22.8 \%)\end{array}$ \\
\hline XVa & Security issues & $\begin{array}{l}7 \\
7)^{(20.0}\end{array}$ \\
\hline $\mathrm{XVg}$ & $\begin{array}{l}\text { Irreversibility of the outsourcing } \\
\text { decision }\end{array}$ & $\begin{array}{l}6 \\
(17.1 \%)\end{array}$ \\
\hline XVf & $\begin{array}{lllll}\text { Incapacity to } & \text { adapt } & \text { to } & \text { new } \\
\text { technologies } & & & & \\
\text { TOTAL } & & & & \end{array}$ & $\begin{array}{l}3 \\
(8.6 \%) \\
105 \\
(300.0 \%)\end{array}$ \\
\hline
\end{tabular}

TABLE VI: FACTORS FOR OUTSOURCING SUCCESS

\begin{tabular}{|c|l|l|}
\hline $\begin{array}{c}\text { C } \\
\text { ode }\end{array}$ & \multicolumn{1}{|c|}{ Variable } & $\mathrm{N}$ \\
\hline XVIa & $\begin{array}{l}\text { The provider must understand the client's } \\
\text { objectives } \\
\text { The top management's support and } \\
\text { involvement } \\
\text { Choosing the right provider }\end{array}$ & $\begin{array}{l}26 \\
(74.3 \%) \\
15 \\
(42.8 \%) \\
13\end{array}$ \\
XVIC
\end{tabular}




\begin{tabular}{|l|l|l|} 
XVId & Frequency of client-provider contacts & $(37.1 \%)$ \\
XVIg & $\begin{array}{l}\text { To pay careful attention to the client's } \\
\text { specific problems }\end{array}$ & $(37.1 \%)$ \\
XVIe & To make a properly drawn-up contract & $(37.1 \%)$ \\
XVIb & $\begin{array}{l}\text { To know what is intended with the use of } \\
\text { outsourcing } \\
\text { A good value for money relation }\end{array}$ & $(25.7 \%)$ \\
XVIh & $(22.8 \%)$ \\
& $\begin{array}{l}\text { TOTAL } \\
(22.8 \%)\end{array}$ \\
& 105 \\
\end{tabular}

TABLE VII: FACTORS TO CHOOSE A PROVIDER

\begin{tabular}{|c|c|c|}
\hline Code & Variable & $\mathrm{N}$ \\
\hline XVIIa & Service quality & $\begin{array}{l}26 \\
(74.3 \%)\end{array}$ \\
\hline $\begin{array}{l}\text { XVII } \\
h\end{array}$ & Previous client-provider relations & $\begin{array}{l}18 \\
(51.4 \%)\end{array}$ \\
\hline XVIIf & Cultural proximity between client and provider & 13 \\
\hline $\begin{array}{l}\text { XVII } \\
g\end{array}$ & The provider's solvency and stability & 13 \\
\hline XVIIc & $\begin{array}{l}\text { The provider's reports and reputation in other } \\
\text { universities }\end{array}$ & $\begin{array}{l}12 \\
(34.3 \%)\end{array}$ \\
\hline $\begin{array}{l}\text { XVII } \\
\text { b }\end{array}$ & & $\begin{array}{l}10 \\
(28.6 \%)\end{array}$ \\
\hline XVII & Contract flexibility & 7 \\
\hline XVIIe & $\begin{array}{l}\text { The provider's resources } \\
\text { TOTAL }\end{array}$ & $\begin{array}{l}6 \\
(17.1 \%) \\
105 \\
(300.0 \%)\end{array}$ \\
\hline
\end{tabular}


TABLE VIII: UNIVERSITY CLUSTERS

\begin{tabular}{|c|c|c|c|}
\hline & $\begin{array}{c}\text { Reasons for } \\
\text { Outsourcing }\end{array}$ & $\begin{array}{c}\text { Reservations about } \\
\text { Outsourcing }\end{array}$ & Outsourcing success \\
\hline $\begin{array}{c}\text { Cluster 1: } \\
\text { Perfectionis } \\
\text { t }\end{array}$ & $\begin{array}{c}\text { IS Improvement } \\
\text { (XIVc, XIVd, XIVf) }\end{array}$ & $\begin{array}{c}\text { Loss of Competences } \\
\text { (XVe, XVg, XVJ) }\end{array}$ & $\begin{array}{c}\text { Depends on the Client } \\
\text { (XVIb, XVIc, XVIf) }\end{array}$ \\
\hline $\begin{array}{c}\text { Cluster 2: } \\
\text { Hesitant }\end{array}$ & $\begin{array}{c}\text { Free from Problems } \\
\text { (XIVe, XIVg, XIVh) }\end{array}$ & $\begin{array}{c}\text { Lack of Conviction } \\
\text { (XVa, XVc, XVf, XVh, XVi) }\end{array}$ & $\begin{array}{c}\text { A Complete, Well- } \\
\text { Structured (Contract XVIe, } \\
\text { XVIh) }\end{array}$ \\
\hline $\begin{array}{c}\text { Cluster 3: } \\
\text { Cost- } \\
\text { Reducing }\end{array}$ & $\begin{array}{c}\text { Cost Saving } \\
\text { (XIVa, XIVb) }\end{array}$ & $\begin{array}{c}\text { Staff-Related Issues } \\
\text { (XVb, XVd) }\end{array}$ & $\begin{array}{c}\text { Depends on the Provider } \\
\text { (XVIa, XVId, XVIg) }\end{array}$ \\
\hline
\end{tabular}

TABLE IX: AGGLOMERATION SCHEDULE USING AVERAGE LINKAGE (BETWEEN GROUPS)

\begin{tabular}{|r|r|r|r|r|r|r|}
\hline & \multicolumn{2}{|c|}{$\begin{array}{c}\text { Clusters } \\
\text { Combined }\end{array}$} & $\begin{array}{c}\text { Coefficie } \\
\text { nt }\end{array}$ & $\begin{array}{c}\text { Stage Cluster 1 } \\
\text { Appears }\end{array}$ & $\begin{array}{c}\text { Next } \\
\text { Stage }\end{array}$ \\
\hline $\begin{array}{r}\text { Stag } \\
\text { e }\end{array}$ & $\begin{array}{r}\text { Cluster } \\
\text { 1 }\end{array}$ & $\begin{array}{r}\text { Cluster } \\
\mathbf{2}\end{array}$ & & $\begin{array}{c}\text { Cluster } \\
\text { 1 }\end{array}$ & Cluster 2 & \\
\hline 1 & 20 & 26 & 0.000 & 0 & 0 & 6 \\
2 & 11 & 16 & 0.000 & 0 & 0 & 8 \\
3 & 22 & 25 & 1.000 & 0 & 0 & 5 \\
4 & 10 & 12 & 1.000 & 0 & 0 & 7 \\
5 & 17 & 22 & 1.500 & 0 & 3 & 8 \\
6 & 20 & 23 & 2.000 & 1 & 0 & 10 \\
7 & 10 & 21 & 2.500 & 4 & 0 & 9 \\
8 & 11 & 17 & 3.000 & 2 & 5 & 17 \\
9 & 10 & 24 & 5.000 & 7 & 0 & 21 \\
10 & 4 & 20 & 5.000 & 0 & 6 & 13 \\
11 & 15 & 19 & 6.000 & 0 & 0 & 15 \\
12 & 1 & 18 & 6.000 & 0 & 0 & 22 \\
13 & 4 & 6 & 6.250 & 10 & 0 & 15 \\
14 & 8 & 14 & 7.000 & 0 & 0 & 16 \\
15 & 4 & 15 & 7.200 & 13 & 11 & 23 \\
16 & 7 & 8 & 7.500 & 0 & 14 & 18 \\
17 & 5 & 11 & 7.600 & 0 & 8 & 20 \\
18 & 7 & 9 & 9.000 & 16 & 0 & 20 \\
19 & 3 & 13 & 10.000 & 0 & 0 & 23 \\
20 & 5 & 7 & 10.667 & 17 & 18 & 24 \\
21 & 2 & 10 & 11.750 & 0 & 9 & 22 \\
22 & 1 & 2 & 12.600 & 12 & 21 & 24 \\
23 & 3 & 4 & 13.143 & 19 & 15 & 25 \\
24 & 1 & 5 & 15.957 & 22 & 20 & 25 \\
25 & 1 & 3 & 19.902 & 24 & 23 & 0 \\
\hline
\end{tabular}


FIGURE 1: DENDROGRAM USING AVERAGE LINKAGE (BETWEEN GROUPS)

Rescaled Distance Cluster Combine

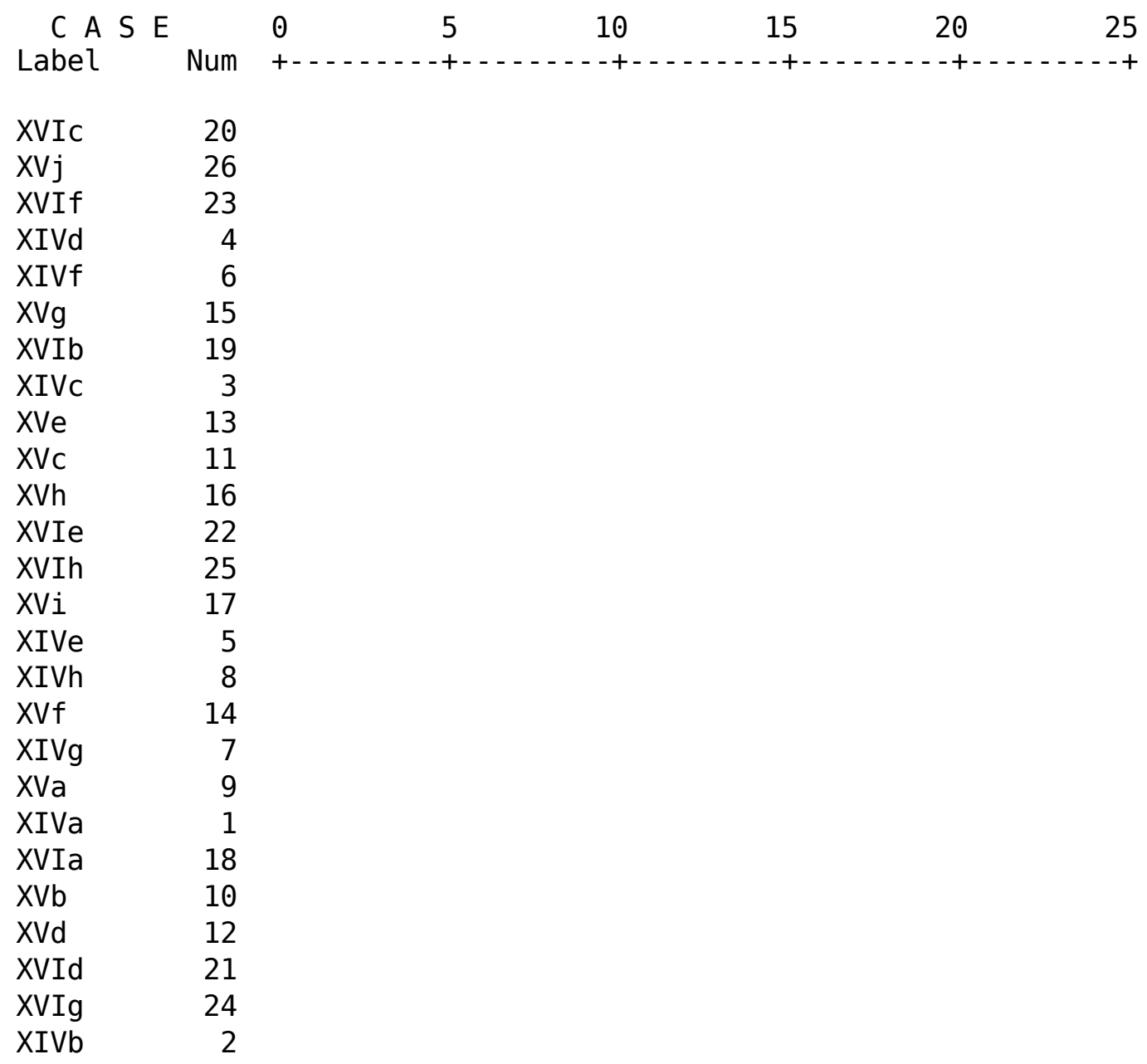

